\title{
Household Waste Management in High-Rise Residential Building in Dhaka, Bangladesh: Users' Perspective
}

\author{
Tahmina Ahsan ${ }^{1 *}$ and Atiq Uz Zaman ${ }^{2}$
}

${ }^{1}$ School of Architecture and Built Environment, University of Adelaide, SA 5001, Australia

${ }^{2}$ Zero Waste SA Research Centre for Sustainable Design and Behaviour, School of Art, Architecture and Design, University of South Australia, Australia

\begin{abstract}
The Dhaka City Corporation (DCC) is primarily responsible for collecting and managing waste in Dhaka, Bangladesh. A significant amount of waste in Dhaka is not collected due to lack of infrastructure, funds and collection vehicles. Despites Dhaka's limited waste management service, community based door-to-door waste collection from households to local waste bins is considered as a success. Informal waste recycling systems is also highly effective in waste recycling and job creations for the poor. Even though both horizontal and vertical expansion is prevalent in Dhaka, there has been an increasing trend in vertical expansion of the city in recent years as horizontal expansion is not possible due to barriers such as the built up urban core and low lying flood plains. Very limited number of studies has been conducted on waste management system in high-rise residential buildings in Dhaka. Therefore, this study focuses on the waste management scenario of high-rise residential buildings in Dhaka. The study is particularly interested in the socio-demographic, cultural and environmental features in high-rise residential buildings. The study identified key areas in waste management systems in high-rise residential buildings which is the avenue for future studies for integrating waste management strategies in high density residential development in Dhaka. Based on the findings, the study recommends a further examination of the integration of waste management infrastructure in the high-rise residential building development in Dhaka.
\end{abstract}

Keywords: Waste management; High-rise residential building; Waste survey; Users' perspective

\section{Introduction}

Cities attract people for the various opportunities it can provide to the inhabitants in terms of income and services. Cities expand both horizontally and vertically to accommodate a huge number of people everyyear. This increasing population in cities produce an ever increasing amount of solid waste every day. Waste management is one of the most challenging and cost effective services that municipality around the globe offers to their citizen. The success of the waste management systems, both in developed and developing countries depends on a holistic waste management planning and adequate facilities Dhaka, the capital of Bangladesh is one of the densely populated cities in the world. Dhaka City Corporation (DCC) provides waste management services for 7 million people living in an area of $360 \mathrm{~km}^{2}$ [1]. The DCC is responsible for collection and disposal of 3000-4000 tons of municipal solid waste from the city's 90 wards (local geo-administrative subdivision) every day. However, the DCC can collect and dispose only $40-50 \%$ of the total waste generated every day due to the lack of funds and infrastructure (Dhaka City Corporation, 2013). Only 14-17\% of the total municipal budget is used for solid waste management which is approximately 0.5 USD per capita per year. As a result, the uncollected waste is primarily dumped illegally in the neighbourhood's streets, wastewater drains, ponds, lakes etc. or managed informally [2]. A significant amount of health and environmental problems are created by the improper waste management systems in Dhaka.

Due to the lack of waste management services from the local authority in Dhaka, private and community based waste management systems have been introduced recently. However, the recent waste management initiatives are facing various complex management challenges. The key challenges are storing, separation and collections of various types of waste from residential areas. Lack of common and uniform waste infrastructures is highly visible in housing sector in Dhaka which. In addition to this difficulty, residential buildings in
Dhaka are of different types such as single-unit low-rise residences, multi-unit apartments, high-rise apartments and apartment complexes with both low-rise and high-rise apartments. Most of the residential housing in Dhaka does not meet the rules of the national building code. In addition, proper guideline on waste management systems is also absent in the national building code. This discrepancy creates additional challenges to the waste management authority.

As a mega city, Dhaka accommodates thousands of people every day. Hence, the number of residential buildings is increasing every year. Almost all available land area in Dhaka has now been used due to urbanization. As a result of limited horizontal land space in Dhaka, urban growth has now begun vertically through high-rise developments. Thus, the number of high-rise residential building is increasing significantly in Dhaka. It is important to understand that the people living in high-rise residential buildings would have different socio-economic conditions compared to other residential buildings in Dhaka. Hence, waste generation and management is also different in high-rise residential building compared to other housing types.

This study primarily focuses on exploring the existing waste management systems in high-rise residential building in Dhaka. Key challenges and opportunities will be identified in the study.

*Corresponding author: Tahmina Ahsan, School of Architecture and Built Environment, University of Adelaide, SA 5001, Australia, Tel: +61 88313 4587; E-mail: tahmina.ahsan@adelaide.edu.au

Received October 30, 2013; Accepted January 15, 2014; Published January 29 2014

Citation: Ahsan T, Zaman AU (2014) Household Waste Management in HighRise Residential Building in Dhaka, Bangladesh: Users' Perspective. Int J Waste Resources 4: 133. doi: 10.4172/2252-5211.1000133

Copyright: $\odot 2014$ Ahsan T, et al. This is an open-access article distributed under the terms of the Creative Commons Attribution License, which permits unrestricted use, distribution, and reproduction in any medium, provided the original author and source are credited. 


\section{Waste Management in Dhaka}

The Dhaka City Corporation (DCC) is primarily responsible for collecting and managing waste in Dhaka. Waste management systems in Dhaka are primarily based on informal waste collection and recycling system. About 120,000 urban poor from the informal sector are involved in the recycling trade chain of Dhaka City. $15 \%$ of the total generated wastes in Dhaka (mainly inorganic) amounting to 475 tons/ day are recycled daily [3]. Informal waste collection and management is not operated and controlled by the local authority (DCC for instance).

Waste is thrown on roadside and places other than dustbins due to lack of proper and sufficient waste infrastructure (bins) and collection systems in Dhaka. About 7146 cleaners are employed by DCC for street sweeping and collection of waste found in places other than dustbins, road side, open spaces, ditches etc. by hand trolley. DCC has 2,080 hand trolleys for primary collection of waste. DCC has 128 demountable container carrier trucks for collection of accumulated waste in 414 containers and 242 open trucks to collect waste from municipal bins at different locations [4].

A direct consequence of the poor performance of waste management services provided by the local government is the growth of communitybased initiatives, private and non-government organizations, which are increasingly playing an important role in delivering conservancy services [5]. Inorganic waste such as paper, plastic, metal, glass and so on is mostly sorted at household level. Doo-to-door recyclables buyer locally known as 'feriwalla' buy sorted recycling waste. In the community based waste collection system, waste collector locally known as 'gariwalla' collects waste (mostly organic and mixed waste) from every household and transfers it to the designated roadside municipal collection points. Informal waste pickers locally known as 'tokai' further sort and collect recyclable materials from waste [1]. Waste is then transferred to the landfill site where another sorting and recycling activities are carried out by the informal recyclers. The following Figure 1 illustrates the waste flow in waste management systems in Dhaka.

\section{Waste management expenditure in Dhaka}

The quality and reliability of the waste management services depend

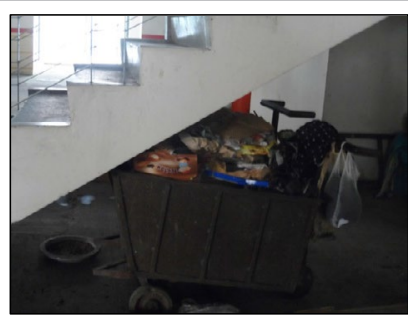

(a) waste storage

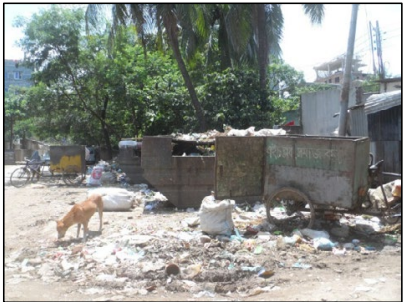

(c) street-side waste bin

Figure 1: Household's waste management system in Dhaka significantly on both infrastructure and operational budget to run the systems effectively. Waste management revenue expenditures in DCC is projected in 17.80 crore tk (USD $2.28 \mathrm{M}$ ) ${ }^{1}$ which is only $8.68 \%$ of total revenue expenditures in DCC [6]. Total projected income of Dhaka North City Corporation (DNCC) in 20131984.53 crore tk and total projected expenditures is 1984.53 crore tk. Table 1 shows the comprehensive waste expenditures in Dhaka. Raising public awareness and promoting recycling through different awareness and training programmes are important. However, from the budget allocation on waste management systems in Dhaka, it is apparent that there is no fund for training programmes.

Government and non-government initiatives through public private partnership (PPP) are playing an important role in waste management development in Dhaka. The project 'Improvement of solid waste management in Dhaka city towards the low carbon society through enhancing waste transport capacity' has allocated about USD $2.04 \mathrm{M}$ for improving waste management systems in Dhaka. Most of the private solid waste management in Dhaka City is based on Public Private Partnership (PPP) mechanism. Dhaka North City Corporation fully privatizes its conservancy works in Uttara, Gulshan, Banani, Baridara, Mohakali and Tejgaon areas. The Private parties do the street sweeping, drain cleaning, door-to-door waste collection, dustbin cleaning and waste transportation and final disposal to landfill [6].

\section{Similar studies in waste management systems in Dhaka}

A number of studies have been done on waste management systems in Dhaka and study includes Afroz et al. in willingness to pay for waste management improvement in Dhaka city [7]. Facilitating people's participation in public-private partnerships for solid waste management in Dhaka [8]. In city governance and its impact in waste management system [5]. Enayetullah et al. in exploring waste management scenario in Uttara Model Town [9]. The effect of waste composting and landfill location [10]. The problem identification and nature of waste management problems in Dhaka [11]. Matter et al. in improving informal waste recycling through segregation of household waste [2]. In socio-cultural practices in household waste collection system from residential buildings [12]. In Waste management modelling in Dhaka [13]. Zaman studied in informal waste management in Dhaka and proposed an innovative social business model based on recycling materials [14].

\section{Rationale and scope of the study}

High-rise residential development is significantly important for the urban development in Dhaka. Hence, high-rise residential building must be the inevitable solution to cater for the urgently needed housing units in densely packed urban areas in Dhaka. Most of the private housing development is based on high-rise apartment housing. The government has planned the country's largest apartment project in Uttara to accommodate ever increasing population in Dhaka. The project proposed approximately 240 no's of 16 storied apartments in total 20,160 no of flats which would accommodate approximately more than 80,000 people in a single development project in Dhaka [15]. Combining all the high-rise development in Dhaka city the number would be significantly higher. Waste management system for high-rise residential buildings in particular, requires different infrastructure and management plans. Therefore, mega cities in developed countries such as Tokyo, Shanghai and New York have different waste management strategy and plan for high-rise residential buildings which is absent in the case of Dhaka. There is no such waste collection and management

${ }_{11} \mathrm{USD}=77.9 \mathrm{BDT}$ as on 30th September 2013 currency conversion rate 
Citation: Ahsan T, Zaman AU (2014) Household Waste Management in High-Rise Residential Building in Dhaka, Bangladesh: Users' Perspective. Int J Waste Resources 4: 133. doi: 10.4172/2252-5211.1000133

\begin{tabular}{|c|c|c|c|}
\hline Key Areas & $\begin{array}{l}\text { Expenditures' } \\
\text { Subsectors }\end{array}$ & $\begin{array}{c}\text { Amount of } \\
\text { expenditures (in } \\
\text { Crore TK) }\end{array}$ & Reference section \\
\hline $\begin{array}{l}\text { Maintenance and } \\
\text { protection }\end{array}$ & $\begin{array}{l}\text { Solid waste } \\
\text { workshop }\end{array}$ & 1.5 (US\$ 192,400) & $\begin{array}{c}\text { subsection } 3.7 \\
\quad(p-5)\end{array}$ \\
\hline Supply & Equipment & 2.5 (US $\$ 320,650)$ & $\begin{array}{c}\text { subsection } 5.6 \\
(p-5)\end{array}$ \\
\hline \multirow{5}{*}{$\begin{array}{l}\text { Urban Waste } \\
\text { Management }\end{array}$} & $\begin{array}{c}\text { Community waste } \\
\text { management }\end{array}$ & $0.3($ US $\$ 42,764)$ & $\begin{array}{c}\text { subsection } 16.1 \\
(p-7)\end{array}$ \\
\hline & $\begin{array}{l}\text { Privatised waste } \\
\text { management }\end{array}$ & 15 (US\$ 1923,900) & $\begin{array}{l}\text { subsection } 16.2 \\
(p-7)\end{array}$ \\
\hline & $\begin{array}{l}\text { Special cleaning } \\
\text { activities }\end{array}$ & 1.5 (US\$ 192,400) & $\begin{array}{l}\text { subsection } 16.3 \\
(p-7)\end{array}$ \\
\hline & Landfill operation & 1 (US\$ 128,260) & $\begin{array}{l}\text { subsection } 16.4 \\
(p-7)\end{array}$ \\
\hline & Subtotal: & 17.80 (US\$ $\$ 2.28 \mathrm{M})$ & Section $16(p 4)$ \\
\hline \multirow[t]{2}{*}{$\begin{array}{l}\text { Infrastructure and } \\
\text { development }\end{array}$} & $\begin{array}{c}\text { Waste } \\
\text { infrastructure (ward } \\
\text { office) }\end{array}$ & 0.5 (US\$ 64,130) & $\begin{array}{c}\text { subsection } 4.12 \\
(\mathrm{p}-8)\end{array}$ \\
\hline & $\begin{array}{c}\text { Waste } \\
\text { management } \\
\text { workshop }\end{array}$ & 0.25 (US $\$ 32,065)$ & $\begin{array}{c}\text { subsection } 4.13 \\
(p-8)\end{array}$ \\
\hline \multirow[t]{2}{*}{$\begin{array}{c}\text { Environmental } \\
\text { development }\end{array}$} & $\begin{array}{l}\text { Dustbin/transfer } \\
\text { station }\end{array}$ & 1.5 (US\$ 192,390) & $\begin{array}{l}\text { subsection } 5.4 \\
(p-9)\end{array}$ \\
\hline & $\begin{array}{l}\text { Landfill operation } \\
\text { and development }\end{array}$ & 5 (US\$ 641,300) & $\begin{array}{c}\text { subsection } 5.7 \\
(p-9)\end{array}$ \\
\hline $\begin{array}{l}\text { Equipment and } \\
\text { assets }\end{array}$ & $\begin{array}{c}\text { Trucks/Motorcycles } \\
\text { for waste } \\
\text { management }\end{array}$ & 5 (US\$ 641,300) & $\begin{array}{l}\text { Sub section } 3 \text { in } \\
\text { sec } 11(p-10)\end{array}$ \\
\hline $\begin{array}{c}\text { Public-private } \\
\text { partnership project }\end{array}$ & $\begin{array}{l}\text { Improvement } \\
\text { of solid waste } \\
\text { management in } \\
\text { Dhaka city towards } \\
\text { the low carbon } \\
\text { society through } \\
\text { enhancing waste } \\
\text { transport capacity }\end{array}$ & 15.91 (US\$ 2.04M) & $\begin{array}{c}\text { Subsection } 1.11 \\
(p-11)\end{array}$ \\
\hline
\end{tabular}

Table 1: A comprehensive budget for waste management in Dhaka city (DNCC, 2013).

strategy in any high-rise residential building in Dhaka. Thus this study is primarily interested to explore the socio-demographic, socio-cultural and environmental features in waste management systems in high-rise residential buildings in Dhaka. The authors predict that the findings of this study would be beneficial for the local authority and city planner to integrate waste management planning in the high-rise residential buildings. The study primarily focuses on the socio-demographic, socio-cultural and environmental features of waste management systems in high-rise residential buildings in Dhaka.

\section{Methodology and Method}

A questionnaire survey has been used to explore the waste management scenario in high-rise residential buildings. The survey questionnaire consists of three different parts: socio-demographic, socio-cultural and environmental questions. A total of 117 households were surveyed during February-May 2013. A semi-structured questionnaire was used distributed randomly to occupants of high-rise residential building. The only controlled factor was the building height (according to Bangladesh National Building Code, A BUILDING more than 6 stories is considered as a high-rise building). Figure 2 shows the key indicators used in the questionnaire survey.

The questionnaire was based on the following basic questions:

i. Socio-demographic features
a. Name/address
b. Profession

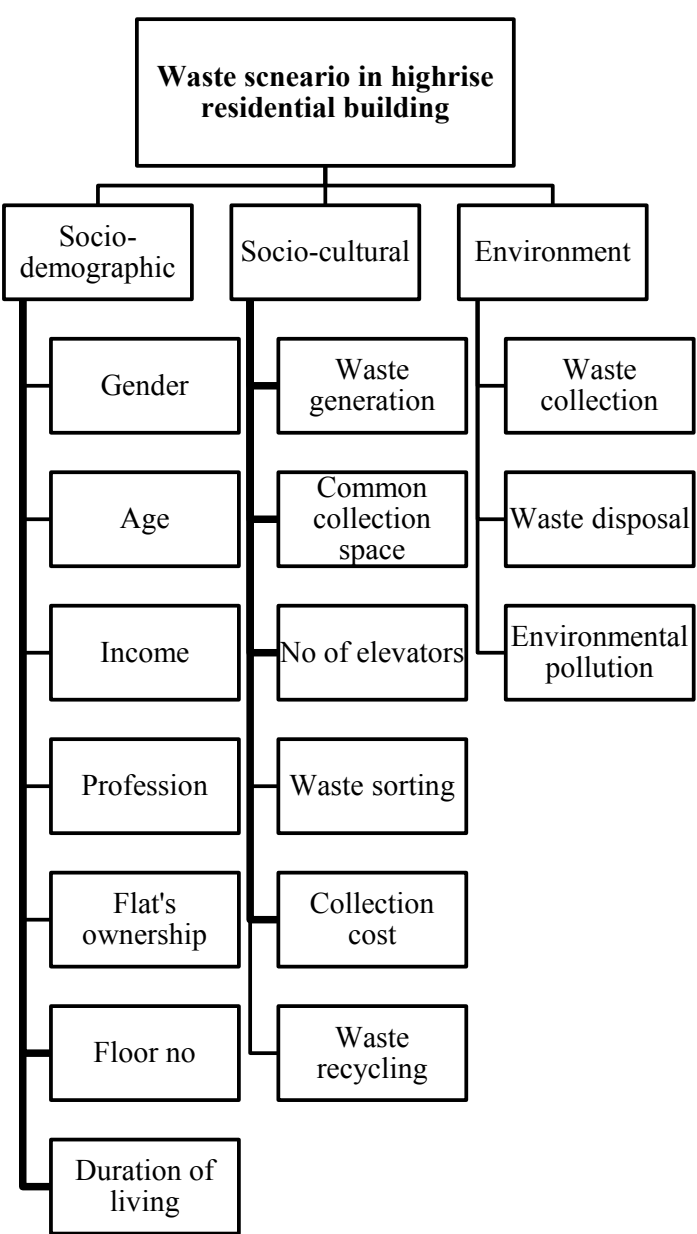

Figure 2: Key aspects in questionnaire survey in waste management in highrise residential building.
c. Gender
d. Income group
e. Flat ownership
f. Floor level
g. Duration of living
h. Household size

i. No of elevators

ii. Socio-cultural features
a. Any designated place for waste storing at household level
b. No of bins used at household level
c. Household waste collection provision
d. Waste collection fees
e. Waste management systems in surroundings areas
f. Awareness program and training on waste management systems

iii. Environmental features
a. Whether waste is collected separately
b. Level of severity of waste problems
c. Knowledge on waste separation 
d. Willingness to recycle

e. Importance of proper waste management system

\section{Results and Discussion}

\section{Socio-demographic features}

Demographic features: As this study focuses on the waste management systems in high-rise residential building in Dhaka, it is important to understand the socio-demographic and economic characteristic of the participants living in the high-rise residential buildings. Table 2 shows the key characteristic of the survey participants'. The questionnaire was distributed to $117(\mathrm{~N}=117)$ flats in 25 different high-rise residential buildings $62 \%$ of the respondents were male and $38 \%$ were female. About $70 \%$ of the participants live in their own apartment, $28 \%$ live in the rented and only $2 \%$ of them live in mortgaged apartments. Living in high-rise building in Dhaka is very expensive and the survey data also reflects the same. A majority (82\%) of the participants belong to the higher income group (above 50,000tk/ month) and only $27 \%$ were from the middle income (25-50,000tk) group. The average household size is 4.54 . The average household size in the residential buildings of Dhaka calculated as 4.7 in 2010, quite close to the size found in this survey [16].

Participants' affiliations: Figure 3 shows the profession and affiliation of the participants.

Floor level surveyed: In this study, the building height (in this study the floor level) and the access to the flats are important factors in waste collection system. Figure 4 shows that, only 17 flats were located in buildings below six storeys and the remaining 100 flats surveyed were located above six storeys. The highest floor level surveyed is the $19^{\text {th }}$ floor $(\mathrm{N}=4)$. Most of the participants were from the $6^{\text {th }}$ to $12^{\text {th }}$ floor level.

No of elevators in the high-rise buildings: Accessibility for waste collection by collectors to the flats in the high-rise residential buildings is regarded as important. The high-rises do not have a service elevator and thus waste needs to be transported by the passenger elevators. An integrated waste collection system such as chute system is not mandatory for high-rise residential building as per the rules in Bangladesh National Building Code Therefore, waste is mostly collected on a door to door basis. It is obvious that every high-rise residential building has at least one or higher number of elevators. Figure 5 shows the Pareto diagram of the elevator number. From figure 5, 61 households have at least one elevator and 33 households have two, 18 households have three and 5 households have four elevators.

Duration of living: As shown in Figure 6, about $80 \%$ of participants have been living in their flats for 6-10 years which is comparatively long. The reason may be owing to the ownership of the flat, i.e. most of the participants own their flats. Community based waste collection systems is different in different wards or local sub-divisions. Long duration of flat occupancy has some benefits on overall waste management systems such as familiarity of wards based collection system, informal waste recycling and so on.

\section{Socio-cultural features}

Any designated place for waste storing at household level: Compared to developed cities, local government in Dhaka does not provide effective waste service to every household. Designated

\begin{tabular}{|c|c|c|c|}
\hline Indicators & & Frequency & Per cent \\
\hline No of unit surveyed $(\mathrm{N})$ & & 117 & $100 \%$ \\
\hline \multirow{2}{*}{ Gender } & Male & 73 & $62 \%$ \\
\hline & Female & 44 & $38 \%$ \\
\hline \multirow{3}{*}{ Housing Ownership } & Own & 82 & $70 \%$ \\
\hline & Rent & 33 & $28 \%$ \\
\hline & Mortgage & 2 & $2 \%$ \\
\hline \multirow{4}{*}{ Income group } & Middle income & 21 & $18 \%$ \\
\hline & Upper-middle income & 31 & $27 \%$ \\
\hline & Upper income & 28 & $23 \%$ \\
\hline & Upper-upper income & 37 & $32 \%$ \\
\hline
\end{tabular}

Table 2: Key features of the participants.

\section{Profession and affiliation}

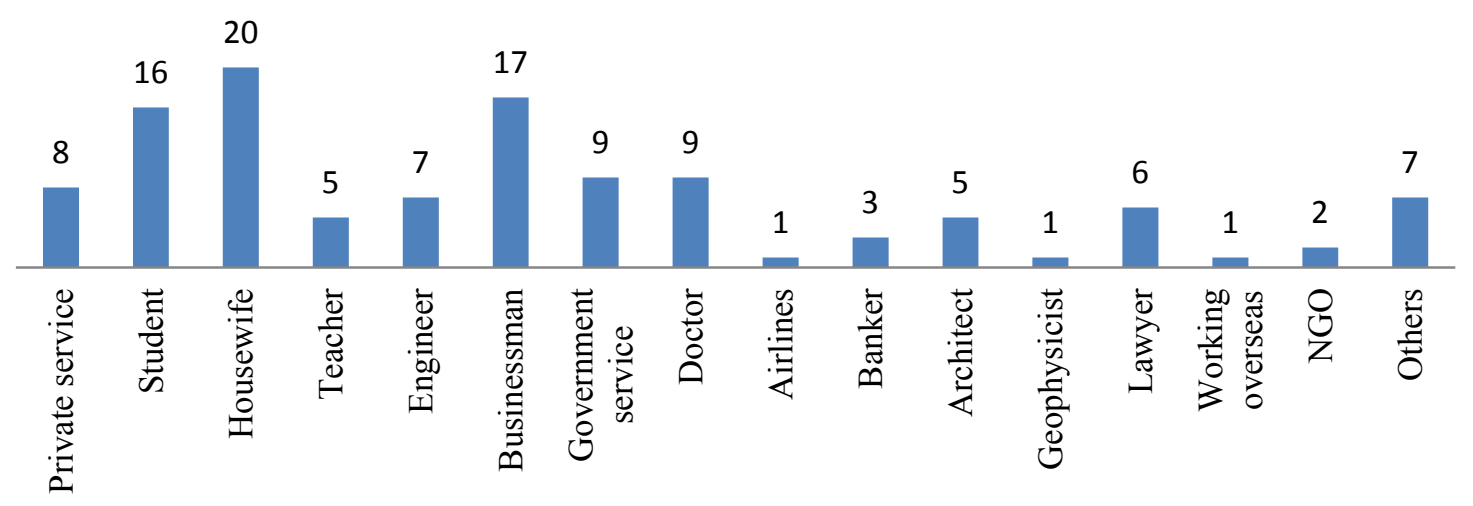

Figure 3: Participants' profession and affiliation. 
Citation: Ahsan T, Zaman AU (2014) Household Waste Management in High-Rise Residential Building in Dhaka, Bangladesh: Users' Perspective. Int J Waste Resources 4: 133. doi: 10.4172/2252-5211.1000133

Page 5 of 7

Frequency of participants' floor level

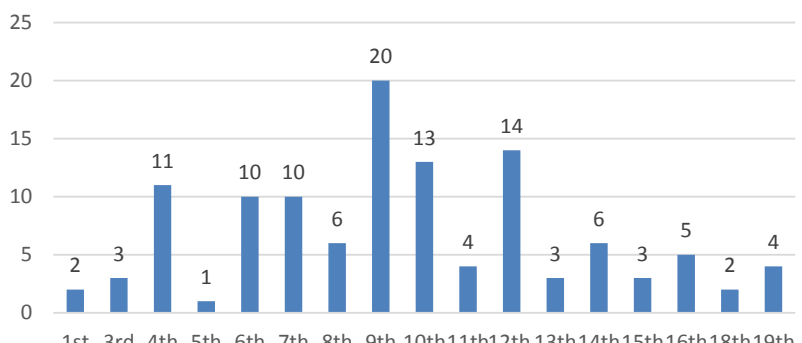

Figure 4: frequency of the floor level surveyed.

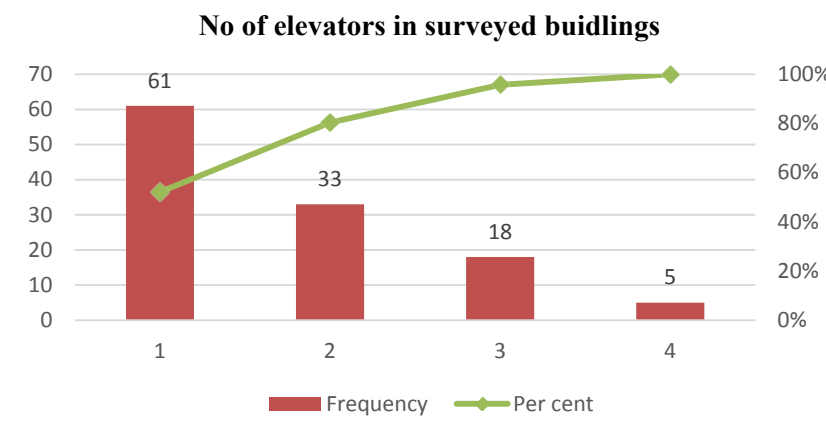

Figure 5: No of elevators.

Participants'occupancy period in flats

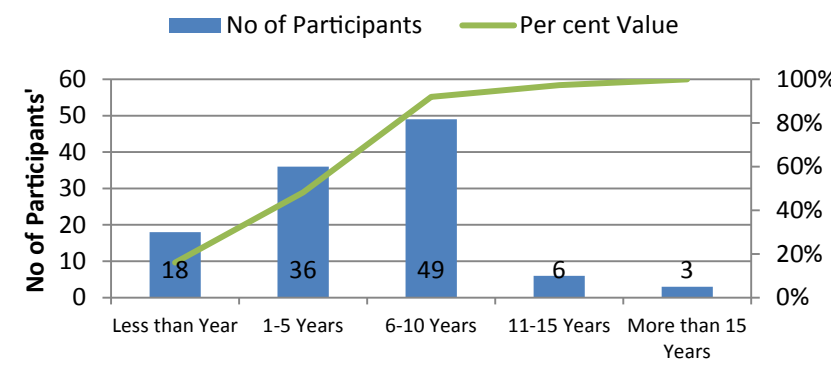

Figure 6: participants' living duration.

place for waste collection system is vital for effective waste collection and recycling systems. As shown in Figure 7, more than $97 \%$ of the households do not have the provision for common waste sorting place. Only $2.6 \%$ of the household have a common sorting place.

No of bins used at household level: Each of the 117 flats surveyed had only bin for collecting their waste. Waste from the individual bins of all the flats are emptied in the bin brought in by the waste collector during the door to door collection service. Even though in some apartment house, recycle bins were provided by the housing society, however they found unused and used inappropriately at the household level. Figure 8 shows the misuse of recycling bin in apartment in Dhaka.

Household waste collection provision: The local government in Dhaka does not collect waste at household level; waste is thus collected by other means and piled to the common garbage collection points such as roadside waste bins. Figure 9 shows the common way of waste collection system in high-rise residential building in Dhaka. Wastes in 111 flats out of the 117 unit were collected by locally recruited collectors under the community based waste collection system. Only 5 flats had garbage chute and in one flat, wast was collected by a servant and transported to the local roadside waste bin.

Waste collection fees: Households waste is collected by community based door-to-door waste collection systems. Residents of the households bear the monthly collection fee. Most of the cases waste fee was included with the apartments' service charges. Approximately 50-200TK (USD 0.75-3) was allocated by every household for monthly waste collection systems, which was very little, compared to other basic services costs.

Waste management systems in surroundings areas: The high-rise residents were asked to rank the overall waste management systems in their neighbourhood. 62 participants (53\%) out of 117 ranked waste management systems in the surrounding community as moderately good, 22 ranked very well and 9 ranked excellent. Only 23 were ranked

Designated storing place for household waste

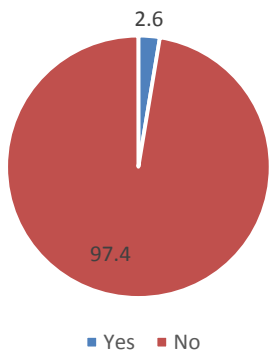

Figure 7: Provision of common storing place in the building.

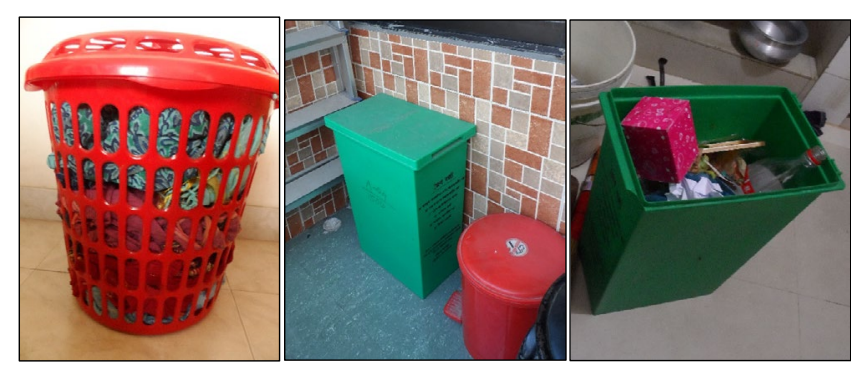

(a) Cloths stored in bin (b) unused bins (c) paper in organic bin

Figure 8: Inappropriate use of recycle bins in apartment house in Dhaka.

Waste collection system from household

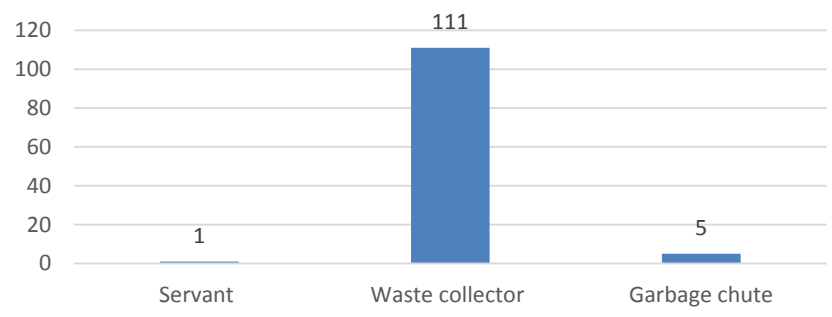

Figure 9: Waste collection from household to common collection points. 
Citation: Ahsan T, Zaman AU (2014) Household Waste Management in High-Rise Residential Building in Dhaka, Bangladesh: Users' Perspective. Int J Waste Resources 4: 133. doi: 10.4172/2252-5211.1000133

Page 6 of 7

waste management systems as' somewhat good' to' poor'. Figure 10 shows the overall quality of waste management systems.

Awareness program and training on waste management systems: Success and effectiveness of waste management depends on the awareness and knowledge on waste management among local residents. However, lack of awareness program and funds makes it a seemingly difficult task to provide awareness to the local community. About $92.3 \%$ of the respondents indicated that no awareness program on waste was provided by local government. Only $7.7 \%$ of the respondents were aware of any kind of awareness program on waste provided by the local government. Figure 11 shows the percentage of waste management awareness programme provide in the surveyed households by the local government through any possible media.

\section{Environmental features}

Whether waste is collected separately: Sorting of waste at household level is very important for higher recycling efficiency. Provisions of formal waste recycling bins are thus important for sorting at household level. Only one household had separate waste collection system and the rest of 116 (99\%) flats had no common separate waste collection system. Table 3 shows the provision of separate waste collection system in the surveyed flats.

Level of severity: Waste collection capacity in Dhaka is not enough to collect all the waste generated each day and hence, dumping of waste at roadside is a common problem in Dhaka. Figure 12 shows the level of severity of waste management systems in Dhaka. 46 participants (39\%) out of $117(\mathrm{~N}=117)$ ranked waste management system in Dhaka as very severe, 36 participants $(30 \%)$ ranked as moderately severe, 32

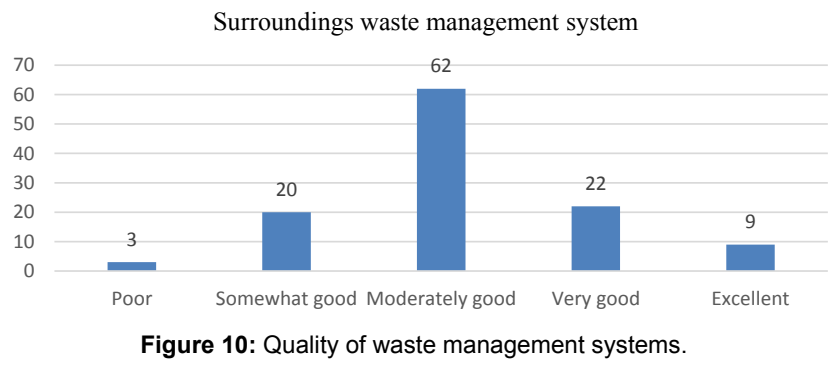

Waste management awareness programme

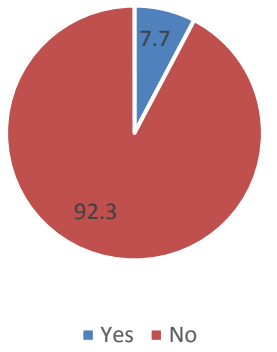

Figure 11: Level of awareness.

\begin{tabular}{|c|c|c|}
\hline Separate waste collection system & Frequency & Per cent \\
\hline Yes & 1 & .9 \\
\hline No & 116 & 99.1 \\
\hline
\end{tabular}

Table 3: Provision of separate waste collection system. participants ranked as somewhat severe and rest of 2 participants were ranked as not severe.

Knowledge on waste separation: Knowledge on waste sorting and recycling is vital for effective waste management services. The socio-economic condition of the participants of this survey is fairly good compared to the national average. Figure 13 shows the level of knowledge on waste separation at household level. Eight participants out of 117 claimed that they have excellent level of knowledge on waste separation. 42 ranked them as good, 41 ranked as moderate, 10 ranked as low and 15 participant said they really do not know about waste separation. Despite overall high level of waste separation by the informal sector, formal waste recycling is not high in Dhaka due to lack of waste infrastructure and absence of formal waste recycling system in place.

Willingness to recycling: The participant were asked whether they were willing to sort, separate and recycle if the bins or provision were provided by the local authority. Majority of the participant showed their willingness to sort waste at household level. From Figure 14, a total 7 participants out of 117 said they are willing to separate at any cost, 45 participants were willing to sort if they can afford the system, 41 participants were willing to sort but due to lack of infrastructure in place they cannot sort time at this moment. Only 10 participants were not willing to sort because they found the system costly and the remaining 13 participants were not willing to sort at all.

Importance of proper waste management system: Figure 15 shows participants' degree of importance on waste management systems. 37 participants (32\%) out of 117 thought waste management system is extremely important, 47 participants $(40 \%)$ though very important, 27 participants ranked as moderately important and only 6 participants ranked waste management as slightly important for the society.

Level of severity of waste management system

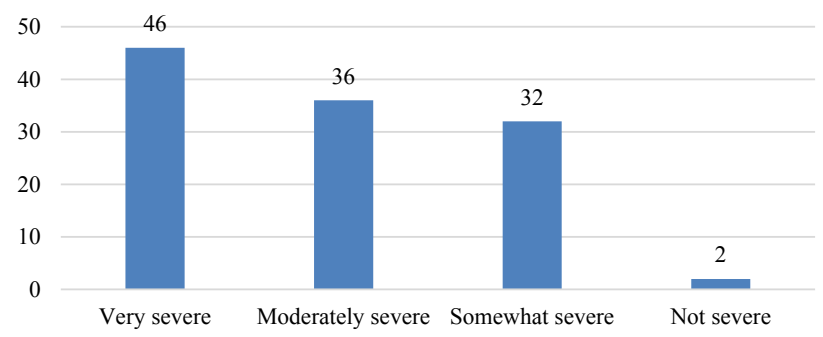

Figure 12: Level of severity of waste management system.

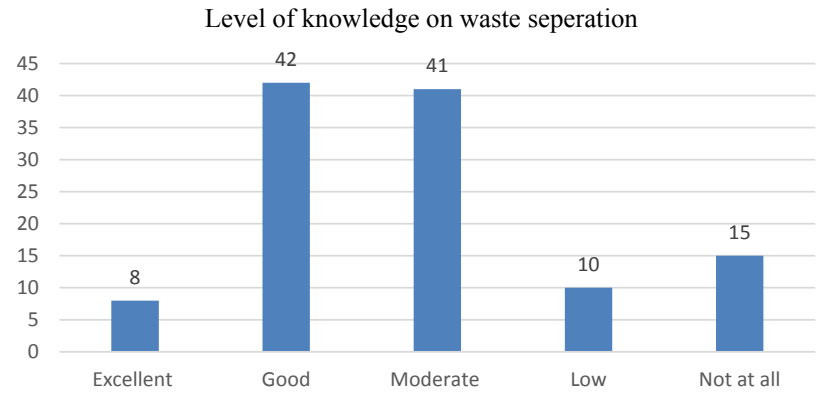

Figure 13: Level of knowledge on waste separation 


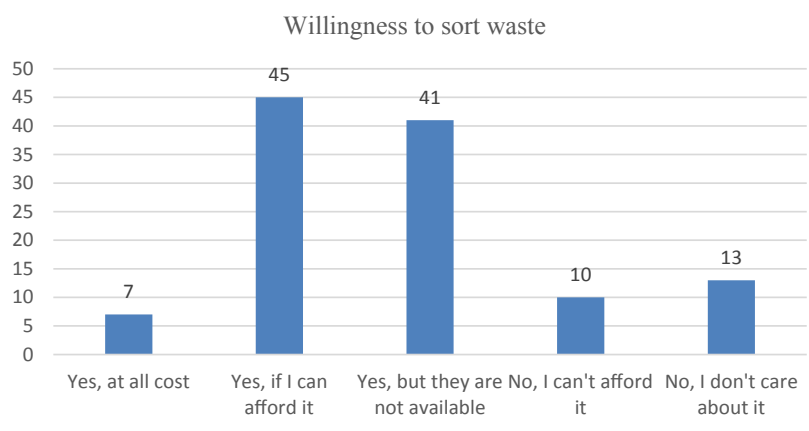

Figure 14: Willingness to sort waste.

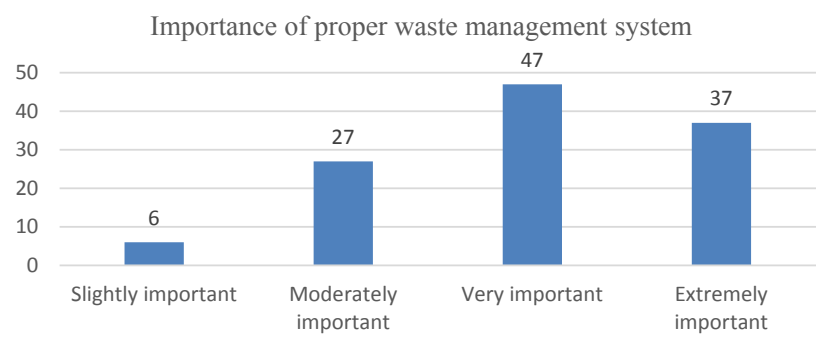

Figure 15: importance of waste management system.

\section{Conclusion and Future Directions}

Waste management systems and techniques vary depending on socio-economic, demographic, geographical and cultural differences. Despite poor waste collection system provided by the local authority in Dhaka, waste management systems in the high-rise residential buildings could be very efficient and different from the waste management systems in the other types of residential buildings for the following e key reasons: (i) income of the high-rise residential users is high compared to other types of residential building users', (ii) no of people live in per capita land area which affects the total households waste generation rate, (iii) fees for waste collection system which ensures frequent waste collection from households, (iv) no of elevation and access to the waste collectors which is not always obvious for every high-rise residential buildings in Dhaka, (v) designated and common waste sorting place to separate and recycle with high efficiency, (vi) total no of bins use for separation, (vii) awareness and recycle training programme and (viii) residents' willingness for recycling.

From the results of the survey findings it is evident that the residents of the high-rise buildings are higher-medium to upper income group people with higher social and economic status. As a result, they are also more aware of social issues such as waste problems in Dhaka. People from the surveyed apartments $(\mathrm{N}=117)$ in Dhaka shows a great sign of willingness to recycle right if the provisions and infrastructure are in place. They are also willing to bear the extra waste management cost. So now it is up to government to provide such infrastructure and service to the users.

The study identified some key areas in waste management systems in high-rise residential building which can be further studied to analyse the need for holistic waste management strategies for high-density residential development in Dhaka.

An extended study can be done to identify the provisions for the integration of waste management infrastructure in high-rise residential buildings. Long term waste collection and management strategies in high-rise residential buildings in Dhaka can be studied more comprehensively.

\section{Acknowledgement}

The authors are very grateful to the respondents who participated in the survey. The authors thank two anonymous referees for their insightful comments.

\section{References}

1. Dhaka City Corporation (DCC) (2013) Solid Waste Management.

2. Matter A, Dietschi M, Zurbrügg C (2013) Improving the informal recycling sector through segregation of waste in the household: The case of Dhaka Bangladesh Habitat International 38: 150-156.

3. Ministry of Environment and Forests (MoEF) (2010) National 3 R strategies for waste management. Government of the People's Republic of Bangladesh.

4. Islam S (2013) Solid Waste Management in Dhaka City

5. Bhuiyan SH (2010) A crisis in governance: Urban solid waste management in Bangladesh. Habitat International 34: 125-133.

6. Dhaka North City Corporation (DNCC) (2013) Waste management budget in Dhaka.

7. Afroz R, Hanaki K, Kiyo HK (2009) Willingness to pay for waste management improvement in Dhaka city Bangladesh. Journal of Environmental Management 90: 492-503.

8. Ahmed SZ, Ali SM (2006) People as partners: Facilitating people's participation in public-private partnerships for solid waste management. Habitat International 30: 781-796.

9. Enayetullah I, Sinha AHMM, Khan KH, Roy KS, Kabir SM, et al. (2006) Report on baseline survey on solid waste management in UttaraModel Town unpublished results.

10. Hai, Faisal I, Ali M, Ashraf A (2005) Study on Solid Waste Management System of Dhaka City Corporation: Effect of Composting and Landfill Location. UAP Journal of Civil and Environmental Engineering 1: 18-26.

11. Hasan S (1998) Problems of municipal waste management in Bangladesh: An inquiry into its nature, Habitat International 22: 191-202.

12. Shah E (1999) Community based separation at source in Bangalore, India

13. Sufian MA, Bala BK (2007) Modelling of urban solid waste management system: The case of Dhaka city, Waste Manag 27: 858-868

14. Zaman AU (2012) Developing a Social Business Model for Zero Waste Management Systems: A Case Study Analysis. Journal of Environmental Protection 3: 1458-1469.

15. Rajuk (2013) Uttara Apartment Project: project information.

16. Bangladesh Bureau of Statistics (BBS) (2001) Population Census Dhaka Bangladesh. 